$-1$

\title{
Financial System and Agricultural Growth in Ukraine*
}

\author{
Olena OLIYNYK-DUNN
}

\begin{abstract}
National University of Life and Environmental Sciences of Ukraine, Economic Faculty
11 Heroyiv Oborony Street, Kyiv, Ukraine

olenaooliynyk@gmail.com
\end{abstract}

\begin{abstract}
Background/Purpose: An effective financial system should increase the efficiency of economic activities. This study provides evidence regarding the importance of financial development for agricultural growth in Ukraine.

Methodology: We used non-integrated and integral indicators, time series and regression analysis to investigate the link between the financial development and agricultural growth.

Results: The results based on integral indicators shows that the financial development does not affect agricultural growth in Ukraine. The study based on non-integrated indicators, which characterizes various aspects of the financial system's banking component and agricultural growth, provided a significant link between the financial system and agriculture growth. The regression models revealed if bank deposits to GDP (\%) increases the value added per worker in agriculture increases exponentially. The results of the study indicate that, agriculture is more sensitive to lending changes than the vast majority of other sectors of the economy. The increasing lending of one UAH (Ukrainian hryvnia) resulted in retail turnover growth of $1.62 \mathrm{UAH}$, while agricultural gross output, growth was UAH 5.06.

Conclusion: Our results reveal a positive relationship between financial system's banking component and agriculture growth in Ukraine. The results indicate the necessity for continued research into further developing universal methodological approaches of appraising the nexus of the financial system's banking component on agriculture growth in general as well separate farm groups. The results of our study has important implications on policy making authorities efforts to stimulate agricultural growth by improving the efficiency of the financial system's banking component.
\end{abstract}

Keywords: Agricultural growth; the integral indicator of the agricultural growth; the integral indicator of the financial development; time series analysis; regression analysis; financial system

\section{Introduction}

Agriculture is considered the main driver of the Ukrainian economy due to its availability of natural factors of production (soil fertility, favorable climatic conditions, etc.). Thereby, agriculture can provide technological, investment and socio-economic recovery in the country. The importance of agriculture is evidenced by the following data: the share of agriculture in the gross domestic product (GDP) of Ukraine is about $14 \%$, of the country's exports - more than $20 \%$ of the total volume. However, according to experts (EFSE, 2012, OECD, 2012), one of the main factors hindering the formation of effective agriculture in Ukraine is the existence of significant restrictions on access to financing for agricultural producers.

However, in existing Ukrainian research, the importance of the financial system for the development of agriculture is intuitively implied but not supported by good factual scientific evidence. Ukrainian research says that the agriculture growth is slowed down without financial development. However, there are several objections against this statement:

Received: March 7, 2017; revised: April 14, 2017; accepted: June 3, 2017

* The article is a revised an extended version of the paper presented at the International Scientific Days 2016 ,,The Agri-Food Value Chain: Challenges for Natural Resources Management and Society", 19-20 May 2016, Faculty of Economics and Management of Slovak University of Agriculture in Nitra, Slovakia 
- For countries with a high proportion of agriculture, agriculture itself is the driver of growth for other sectors and the economy as a whole; therefore, the agricultural growth affects the financial system and not vice versa;

- In developed industrial and post-industrial economies, the development of the financial system can be carried out regardless of the development of agriculture. The growth of lending in the economy as a whole may be accompanied by a decrease in the volume of lending to agriculture because of the processes of redistribution of credit resources between sectors.

- The implementation of large-scale financial support for agricultural producers and rural areas using nonbank instruments significantly reduces the dependence of agriculture on bank lending.

Therefore, we decided to investigate how the financial system affects agriculture in Ukraine. In the literature, we can find numerous studies that explored the link between financial development and economic growth, but only a few studies deal with the impact of the financial system on agriculture. The purpose of this paper is to identify the importance of financial development for agricultural growth in Ukraine.

What were the trends in the development of agriculture and the financial system of Ukraine? Which indicators, integral or non-integrated are better suited to answer the questions concerning the impact of the financial system on agriculture?

\section{Literature review}

When reviewing the literature, we found many studies conducted with the link between financial development and economic growth. Scholars have seriously explored this topic for only the last 20 years. The first attempt to define the relationship between financial development and economic growth was made by Goldsmith (1969). Using cross-country data, Goldsmith found evidence of a positive trend of the ratio of financial institutions' assets to GDP for 35 countries over 1860-1963 (Goldsmith, 1969). Later many authors have extended this line of inquiry and have confirmed Goldsmith's findings. They have applied a variety of approaches to study the relationship between financial development and economic growth. Mostly scientists have used three approaches for the investigation of the finance-growth nexus: cross sectional analysis (or cross-country analysis), a time-series approach, panel data methods (a combination of both techniques). Cross sectional analysis has been used by, King and Levine (1993), Levine and Zervos (1998), Beck et al. (2000), Levine (2002), Rajan and and Zingales (2003). Time-series techniques have been explored by researchers Demetriades and Hussein (1996), Shan and Morris (2002), and Ghirmay (2004). Furthermore, panel data methods have been discussed in recent literature Edison et al. (2002), Manning (2003).

Each of these approaches has made useful contributions to the investigation of the relationship between finance and economic growth. However, as Schmidt emphasized in his work (Schmidt et al, 2006), all approaches suffer from some important limitations which do not allow us to take all the results at face value. The general problem of all empirical studies is that, to examine the relationship between financial development and growth, one has to define appropriate measures of financial development. Researchers came up with various definitions and measures. Some studies use the size of the banking sector typically measured by the deposit liabilities to GDP or bank claims on the private sector to GDP, others use the size of the stock markets, defined as market capitalization to GDP or total value of domestic equities traded on the stock exchanges to GDP. However, these measures have been criticized by others (Schmidt et al, 2006).

The literature review revealed the existence of studies that focus on the relation between the financial system and agriculture. Researchers from developing countries of India, Iran, Indonesia, Pakistan etc., have mostly studied this topic. They used different methods and they tried to answer the question does the financial system affect the agriculture growth in the country. For example, Yazdani (2008) probed co-integration and causal relationship between financial development, capital stock, real interest rate, international trade and agriculture growth in the Iranian economy. The vector autoregressive model (VAR) was used in modelling multivariate relationships. Their findings confirmed that variables are co-integrated for long run association. Causality analysis revealed that financial development affects agriculture growth. However, there exists only a unidirectional causality from GDP growth to financial development.

Sharif et al. (2009) continued the research about the link between financial development and agricultural growth in Iran. They used research methodology which was based on both survey and description methods. The study showed that financial market plays very important role in developing agricultural sector in Iran. As well, the results also indicated that Iranian financial markets are needed financial reforms to improve the performance of the financial sector.

Anthony (2010) explored the role of agriculture credit, interest rate and exchange rate for the Nigerian economy. Using the historical simulation, the results indicated that agriculture credit improves the efficiency of the agriculture sector and the agriculture sector promotes economic growth. The study suggests that governing bodies should prioritize agriculture and launch a comprehensive macroeconomic policy to stimulate the agriculture sector. 
Hye and Wizarat (2011) examined the effect of financial liberation on agriculture growth by employing Cobb-Douglas function in Pakistan using the ARDL bounds testing approach to cointegration. Their results showed that financial liberalization has contributed to improve the performance of agriculture sector in long-andshort runs. A rise in interest rate reduces the growth of agriculture by increasing the cost of production. Capital and the labor force also play roles in enhancing the efficiency of the agriculture sector.

Shahbaz et al. (2013) investigates the relationship between financial development and agriculture growth in Pakistan economy using the Cobb-Douglas function. Their results revealed that financial development has a positive effect on agricultural growth. This implies that financial development plays a significant role in expanding agricultural growth and production.

Yazdi and Khanalizadeh (2014) examine the causal relationship between the dynamic financial development, economic growth and instability in Iran using annual time series covering the period of 1970-2011. The results of the model suggest that there is bidirectional causality between agricultural economic growth and financial development.

For developed EU countries, and Japan, with existing high state financial support, the impact of the financial system on agriculture is not the challenge for the research.

The above research in developing countries showed that researchers used various techniques with varying degrees of complexity. However we didn't find any research there is using some integral indicators for exploring nexus between financial development and agricultural growth. As well, the results of research indicated that financial development has a positive impact on the agricultural growth of these countries.

\section{Methodology}

The most common (traditional) approach to assessing the impact of one research object (phenomenon or process) on the development of another object is based on an analysis of the interdependence of the indicators characterizing both of these objects. This interdependence could be analyzed using different methodological approaches, the most available being the following:

1. Time series analysis.

2. Regression analysis.

These two methodological approaches were chosen to assess the impact of financial development on agriculture in Ukraine from 2004 to 2013.

In a situation where the objects being studied are complex systems (from the point of view of system theory), the analysis of interdependence may involve the use of integral indicators that generalize the characteristics of individual elements of these systems. Since this is the case in this study, it is necessary to determine the relevant integral indicators.

One of main problems of creation of integral indicator of the financial development and agricultural growth is the impossibility of a completely objective assessment of both these phenomena. The financial system and agriculture are so complicated that any scholar's attempt of simulation and evaluation could not provide the absolute face value. Moreover, it is not possible to make adequate assessments, because the objects of assessment are complicated and there is lack of generally accepted objective criteria of valid estimates for these objects.

The last statement asserts the impossibility of creating a complicated model of finance-growth nexus estimation, which consist of wide database and many indicators and requires using complex mathematical methods. However, it is unacceptable to provide an over-simplified evaluation, leading to simple generalizations and subjective expert assessments of certain aspects of the finance-growth nexus and contradicts the principles of scientific knowledge.

In our opinion, the best option for solving methodological problems of evaluation of the finance-growth nexus is compliance of the concept of "moderate middle way", which provides ${ }^{1}$ :

- using publicly available statistical data - quantitative objective indicators calculated using generally accepted methods and openly published on the Internet;

- maximum avoidance of subjective assessments and indicators that are characterized by uncertainty regarding the methods of collection or calculation;

- using the mathematical approaches of the average level of complexity and using average dimension data sets. However, data sets must be sufficient to identify the main statistical regularities on base of regression analysis;

- visualization of assessment results.

We suggest using the principles of concept of "moderate middle way", which is mentioned above, to build the simplified model of integral indicator of level development, which is associated with generalization of the three type's indicators: 1) scale (extensity development); 2) resources; 3) efficiency. The composition of these indicators is illustrated in the Table 1. These indicators are calculated according to the methodology of the World Bank and is available at its website (World Bank 2016a, 2016b).

We divide the financial system into two components banking sector and financial markets. We propose to call the model of the integral indicator of the relative level of the financial development as $« 3+3 »$, which allows simplicity and affordability, but quite adequate, provide a comparative analysis of financial system of individual countries 
and identify their type (bank-based or market-based) ${ }^{2}$.

We offer to consider the significance of each indicator as equal. It avoids result distortion, associated with subjective judgments, regarding the ranking of each indicator.

The integral indicator of level development is calculated as an area of the geometric figure (triangle is for economic and agricultural growth, hexagon - for financial system), with the tops in a coordinate system of 3 or 6 axes. Each axis corresponds to one of the indicators listed in the Table 1. On each of the three or six axes, we plot the relative values, which are defined as a share of the maximum (or reference) value of the indicator.

The integral indicator of the financial development level as an area of the hexagon can be calculated by the formula:

$I_{F S}=\frac{1}{2} \times\left[\left(I_{1} \times I_{2}\right)+\left(I_{2} \times I_{3}\right)+\ldots+\left(I_{6} \times I_{1}\right)\right] \times \sin 60^{\circ}$

where $\mathrm{II}_{F S}$ - the integral indicator of the financial development level;

$\mathrm{I}_{1}, I_{2}, \ldots I_{6}$ - relative values of indicators used in the model " $3+3$ " (6 indicators): $I_{l}, I_{2}, I_{3}$ - relative values of banking sector indicators, $I_{4}, I_{5}, I_{6}-$ relative values of the financial market indicators (see table 1).

The integral indicator of the economic growth level as an area of the triangle can be calculated by the formula:

$I_{E G}=\frac{1}{2} \times\left[\left(I_{1} \times I_{2}\right)+\left(I_{2} \times I_{3}\right)+\left(I_{3} \times I_{1}\right)\right] \times \sin 120^{\circ}$

where $\mathrm{II}_{E G}$ - the integral indicator of the economic growth level;

$\mathrm{I}_{I}, I_{2}, I_{3}$ - relative values of indicators of scale, resources and efficiency.

The integral indicator of the agricultural growth is calculated as well as the integral indicator of the economic growth level by the formula 2 using three indicators according to the table 1 .

The integral indicator describes the relative development level and it cannot be calculated only for one country for one year without comparison with another country or establishing reference values or time-series data ${ }^{3}$.

\section{Results}

If the level of the financial system significantly affects agricultural growth, then, obviously, we should observe a significant statistical relationship between the relevant integral indicators. However, the conducted research has revealed that the relationships between the integral indicators of the financial system and agriculture in Ukraine for
2004-2013 are not observed (see Figure 1).

Consistent statistical patterns between integral indicators of financial development and agricultural growth are absent, but a strong relationship between the integral indicator of financial development and economic growth is present. In this case, we can assume that agriculture should be viewed as one of those industries, for which the complex impact of the financial system does not have significant value.

In general, the relatively stable development of Ukrainian agriculture took place with turbulent financial system and economic development processes in the background (Figure 2).

The study reveals a strong statistical relationship between integral indicator of financial development (taken with 1 year in advance) and the integral indicator of economic growth of Ukraine (Figure 3), despite the fact that any similar interdependencies with integral indicator of agricultural growth were not observed.

Absence of a relationship between two integral indicators in Figure 1 does not give any reasons to conclude that the development of financial system does not influence the development of agriculture in Ukraine. Important relations may exist between indicators characterizing separate aspects of financial system and agricultural growth.

Despite the relatively small number of observations (only 8 values), the regression model is statistically significant and adequate. This confirms the following: 1) the significant value of the coefficient of determination (R-squared) in Figure 3; 2) p-values for the slope coefficient and the constant in the equation -0.0011 and 0.0044 , respectively; 3 ) the residuals show a random character; 4) heteroskedastic effect is not observed.

Taking into consideration only the financial system's banking component as the most significant one (as many researchers assume) for small and medium agricultural producers, and analyzing the correlation between its integral indicator and separate indicators of agricultural growth, we identify certain statistical dependencies (Table 2).

Most notably, in the Table 2 we can observe a strong negative correlation between the development of the financial system's banking component and value added in agriculture (\% of GDP). Regression models (Figure 4) illustrate the identified dependencies.

In Ukraine, the relationship between the developments of the banking component and value added per worker in agriculture is very weak. This fact, combined with the existence of an inverse relationship between the development of the banking component and value added in agriculture (Figure 4), can be evidence to the following: agriculture in Ukraine should be viewed as an industry for which the complex influence of the banking component of the financial system is insignificant or negative.

2 A more detailed explanation of the model " $3+3$ " is in Oliynyk at al (2015).

3The more detail explanation of the concept of "moderate middle way" is Wasilewski at el (2015). 
Table 1: The indicators of the simplified model of the integral indicator

Source: own development based on data (World Bank 2016a, 2016b).

\begin{tabular}{|c|c|c|c|}
\hline \multirow[b]{2}{*}{ The integral indicator } & \multicolumn{3}{|c|}{ Components of integral indicator } \\
\hline & $\begin{array}{l}\text { Scale (extensity develop- } \\
\text { ment) }\end{array}$ & The resources & The efficiency \\
\hline \multicolumn{4}{|l|}{$\begin{array}{l}\text { 1. Financial develop- } \\
\text { ment: }\end{array}$} \\
\hline banking sector & $\begin{array}{l}\text { Commercial bank branches } \\
\quad(\text { per } 100,000 \text { adults })\end{array}$ & Bank deposits to GDP (\%) & $\begin{array}{c}\text { Domestic credit to private } \\
\text { sector by banks ( } \% \text { of } \\
\text { GDP) }\end{array}$ \\
\hline financial markets & $\begin{array}{l}\text { Listed domestic companies } \\
\quad \text { (per 1,000,000 adults) }\end{array}$ & $\begin{array}{l}\text { Market capitalization of } \\
\text { listed companies }(\% \text { of } \\
\text { GDP) }\end{array}$ & $\begin{array}{l}\text { Stocks traded, total value } \\
\text { ( } \% \text { of GDP) }\end{array}$ \\
\hline 2. Economic growth & $\begin{array}{l}\text { Employment to population } \\
\text { ratio, } 15+, \text { total }(\%) \text { (mod- } \\
\quad \text { eled ILO estimate) }\end{array}$ & $\begin{array}{l}\text { Gross capital formation }(\% \\
\text { of GDP) }\end{array}$ & $\begin{array}{c}\text { GDP per capita (current } \\
\text { US\$) }\end{array}$ \\
\hline 3. Agricultural growth & $\begin{array}{c}\text { Arable land (hectares per } \\
\text { person) }\end{array}$ & $\begin{array}{l}\text { Agriculture, value added } \\
\qquad(\% \text { of GDP) }\end{array}$ & $\begin{array}{c}\text { Agriculture value added } \\
\text { per worker (constant } 2005 \\
\text { US\$) }\end{array}$ \\
\hline
\end{tabular}

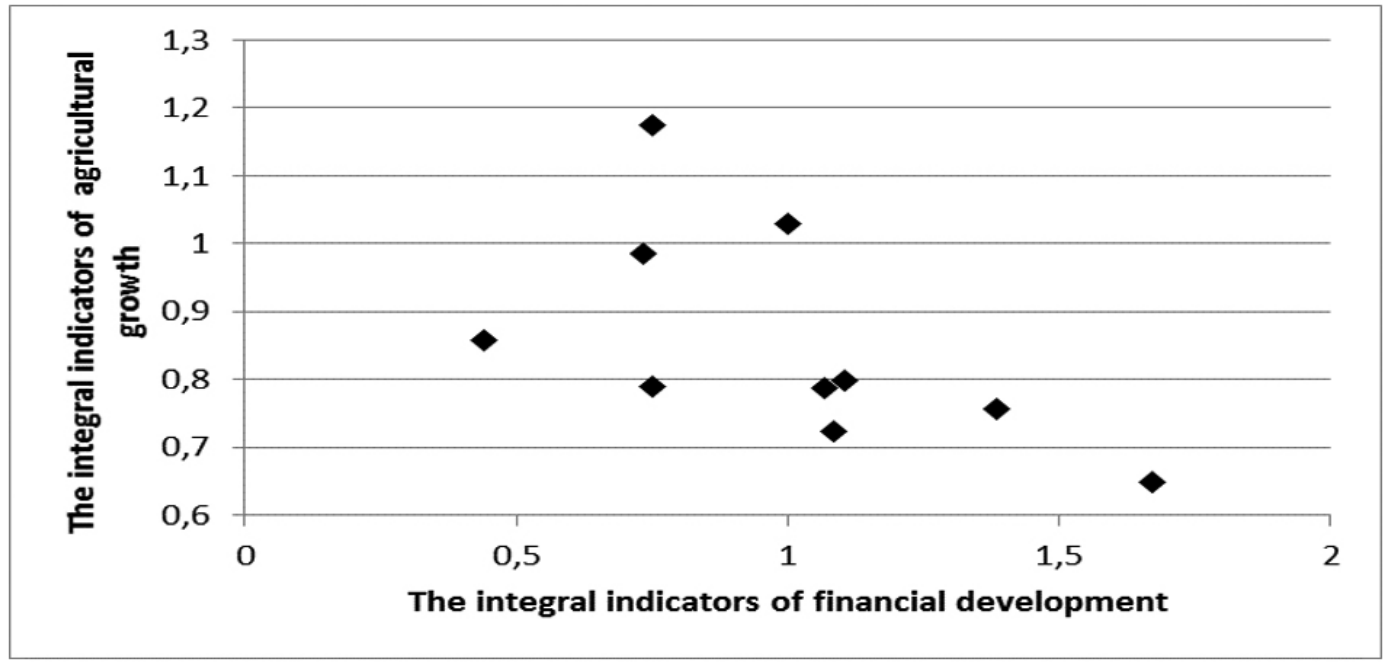

Figure 1: The interdependence between the integral indicators of financial development and agricultural growth in Ukraine, $2004-2013$

Source: author calculations based on data (World Bank 2016a, 2016b).

\section{Discussion}

The obtained results of the analysis of empirical data are debatable, therefore they are subject to verification and confirmation. Thus, we attempted to check two assumptions based on statistical data of the National bank of Ukraine.

The first assumption: the presence of the above mentioned inverse correlation is the result of the fact that the Ukrainian agriculture is less dependent on bank credit compared to other sectors of the economy. According to this assumption, the development of Ukraine's banking component leads to increases in the value added of other economic sectors resulting in the decrease of agricultures share of the GDP.

But this assumption is not confirmed (see Table 3). Comparison of lending volumes and amounts of economic activity at current prices revealed that the volume of agricultural production is more sensitive to lending changes than the volume of other sectors and the economy as a whole (Table 3). 


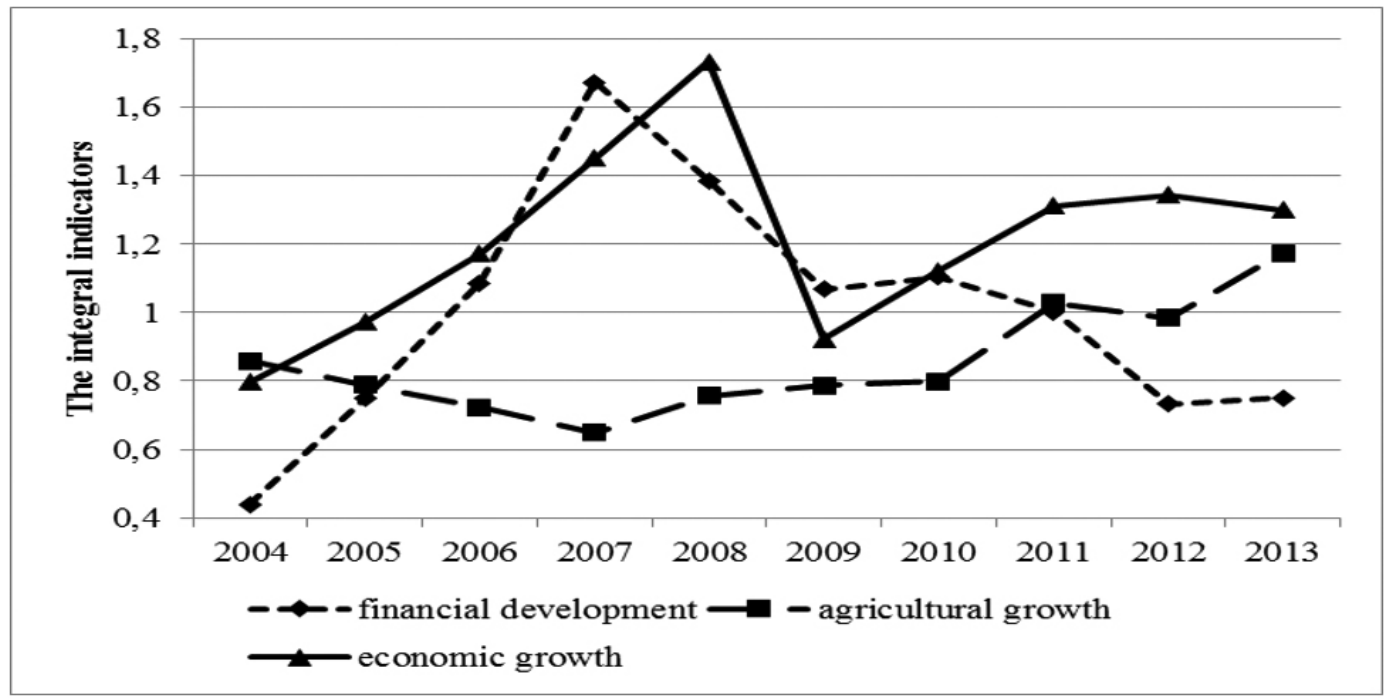

Figure 2. The trend of integral indicators of financial development, economic and agricultural growth in Ukraine, $2004-2013$ Source: author calculations based on data (World Bank 2016a, 2016b).

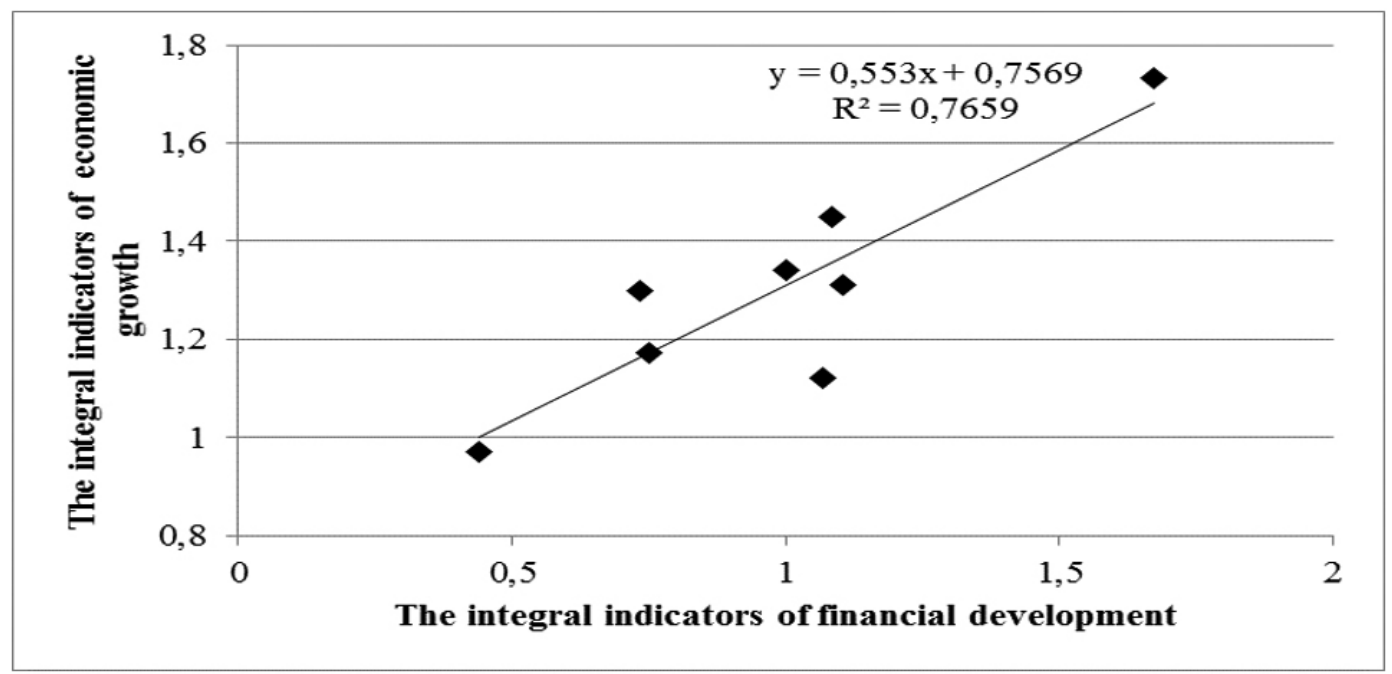

Figure 3. The regression model describing interdependence between the integral indicators of financial development (for the previous year) and economic growth in Ukraine*

Source: author calculations based on data (World Bank 2016b).

*The values of integral indicators of the financial development are for 2004-2012, data of 2008 is excluded; the values of integral indicators of the economic growth are for 2005-2013, data of 2009 is excluded

Particularly, in trade (it was a driver of economic growth in Ukraine during the study period), increasing lending of one UAH (Ukrainian hryvnia) resulted in retail turnover growth of $1.62 \mathrm{UAH}$, while agricultural gross output, growth was UAH 5.06. Comparing agriculture and the economy as a whole identified that agriculture is four times more sensitive to changes in lending.

The research revealed if bank lending increases the gross output of agriculture increases exponentially but nominal GDP growth slows down (see Figure 5, 6). Similarly, the retail trade turnover growth slows down in the case of increasing bank lending.

Revealed patterns not only deny the first assumption, but also illustrate the importance of bank lending for the development of Ukrainian agriculture; it is of even higher significance than for most other sectors and for the economy as a whole.

The second assumption: the inversely proportional 
Table 2: Correlation coefficients between integral indicator of the financial system's banking component and separate indicators of agricultural growth in Ukraine, 2004-2013

Source: author calculations based on data (World Bank 2016a, 2016b).

\begin{tabular}{|c|c|}
\hline The indicator of agricultural growth & $\begin{array}{c}\text { Correlation coefficients with integral indicator of the bank- } \\
\text { ing component of financial system }\end{array}$ \\
\hline $\begin{array}{c}\text { Arable land (hectares per person) } \\
\text { Agriculture, value added (\% of GDP) } \\
\text { Agriculture value added per worker (constant 2005 } \\
\text { US\$) }\end{array}$ & 0,450 \\
\hline
\end{tabular}

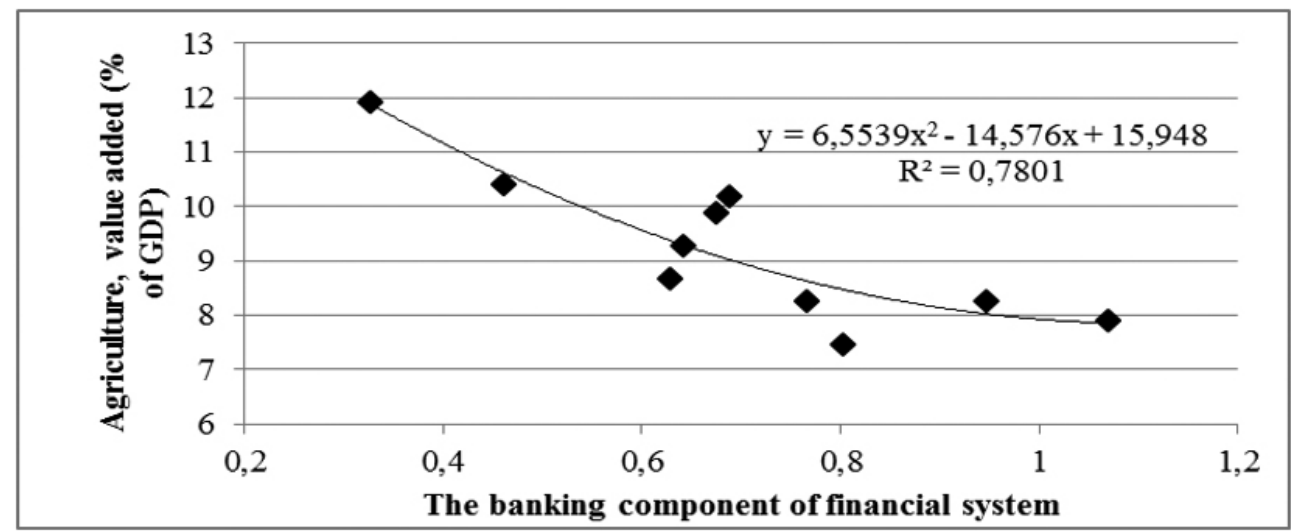

Figure 4: Regression model that describes the relationship between integral indicator of the banking component of financial system and agriculture, value added (\% of GDP) in Ukraine $2004-2013$

Source: author calculations based on data (World Bank 2016a, 2016b).

Table 3: Simple linear regression model parameters describing the relationship between the volume of lending and the volume of economic activity at current prices in Ukraine in 2004-2013

Source: author calculations based on data (World Bank 2016a, 2016b; NBU 2015).

\begin{tabular}{|c|c|c|c|c|}
\hline \multirow{2}{*}{ Industry } & The indicator of the eco- & \multicolumn{2}{|c|}{ Parameters } & \multirow{2}{*}{ R-squared values } \\
\cline { 3 - 5 } & nomic activity & slope coefficient & constant & 0.9224 \\
\hline Agriculture & Gross output & 5.061 & 49.617 & 0.9616 \\
Trade & Retail turnover & 1.619 & 29.481 & 0.9037 \\
\hline
\end{tabular}

relationship between the development of the bank component and the indicator "agriculture, value added (\% of GDP)" in Ukraine relates to the fact, that the indicator "Domestic credit to private sector by banks (\% of GDP)" changes inadequately when elasticity of GDP according to the bank loans is greater than one. In this case, the banking sector development, accompanied by growth in lending to the real sector, leads to relatively higher GDP growth, as a result the domestic credit to private sector by banks ( $\%$ of GDP) decreases.
The second assumption is confirmed by the analysis of the interdependence between the volume of bank credits at current prices and nominal GDP in Ukraine for 2004-2013. It showed that increasing in lending is accompanied by relatively higher GDP growth (as shown in Table 3, lending increasing of one UAH was accompanied by GDP growth of 1.265 UAH). Thus, the existence of the inversely proportional relationship between the integral indicator of the bank component and agriculture, value added ( $\%$ of GDP) in Ukraine does not evidence the negative financial devel- 

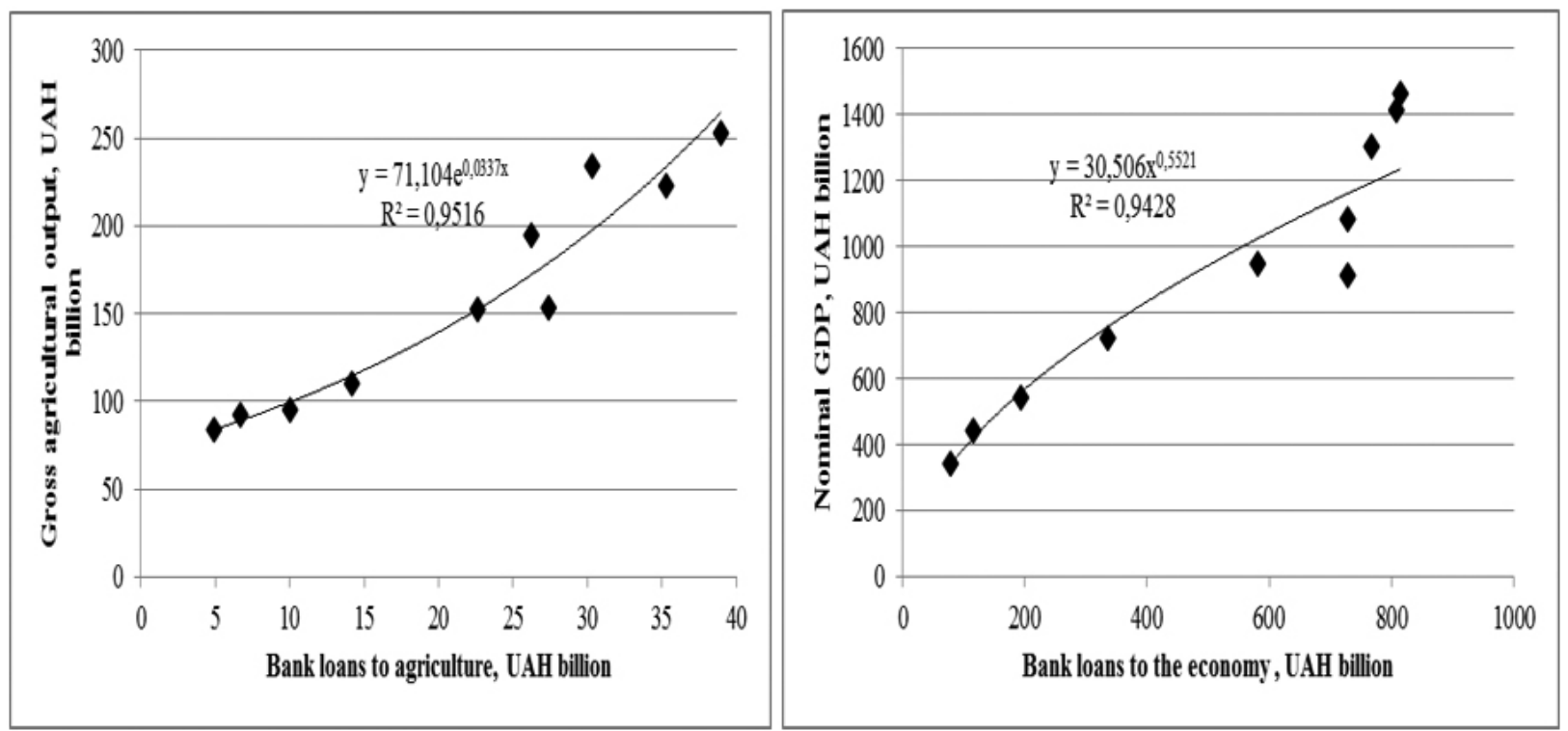

Figure 5 (left): Regression model that describes the relationship between the volume of bank loans to agriculture and the gross agricultural output in Ukraine, 2004 - 2013 (at current prices)

Source: author calculations based on data (World Bank 2016a; NBU 2015)

Figure 6 (right): Regression model that describes the relationship between the volume of bank loans to the economy and nominal GDP in Ukraine, 2004 - 2013 (at current prices)

Source: author calculations based on data (NBU 2015).
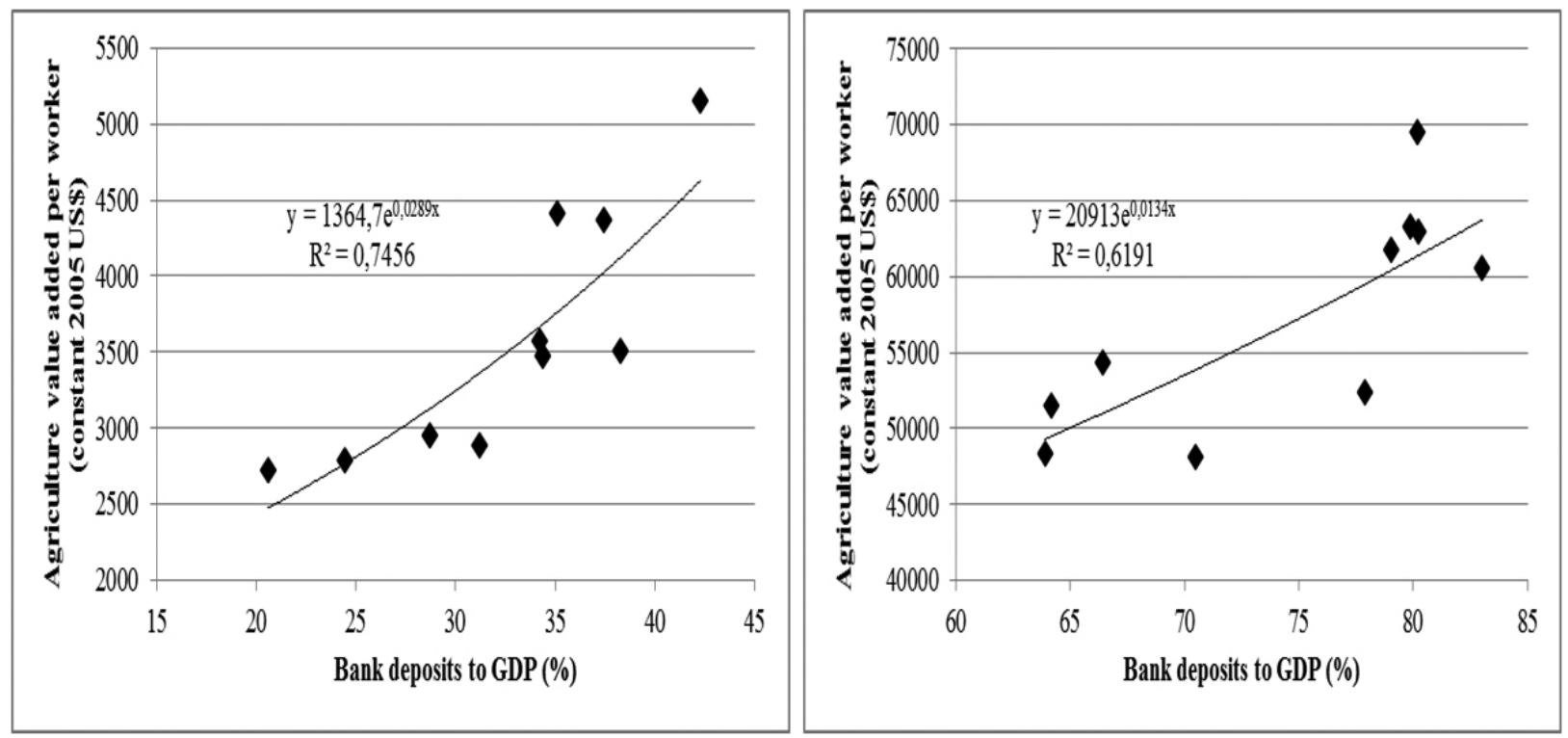

Figure 7 (left): Regression model that describes the relationship between bank deposits to GDP (\%) and Agriculture value added per worker (constant 2005 US\$) in Ukraine, 2004 - 2013

Source: author calculations based on data (World Bank 2016a; NBU 2016).

Figure 8 (right): Regression model that describes the relationship between bank deposits to GDP (\%) and Agriculture value added per worker (constant 2005 US\$) in USA, 2004 - 2013

Source: author calculations based on data (World Bank 2016a; FRS 2015). 
opment impact on agriculture.

The importance of financial development (particularly its banking component) for agriculture of Ukraine is confirmed by the regression model that describes the relationship between bank deposits to GDP (\%) and value added per worker in agriculture (constant 2005 US \$) - see Figure 7 . This model provides an exponential growth rate of value added per worker in agriculture, which may indicate the existence of substantial potential for increasing agriculture productivity, reached by the stimulation of financial development through increasing its resource base. It should be noted that the positive relationship between bank deposits to GDP (\%) and value added per worker in agriculture (constant 2005 US \$) for 2004-2013 was also observed in the US (Figure 8) and in many other countries with developed agriculture.

The market component of the financial system, unlike the banking component, was characterized by the absence of significant statistical dependence of certain aspects of agricultural growth of Ukraine, taking into consideration the integral indicator as well as its separate components.

\section{Conclusion}

Depending on what indicators used integral or non-integrated, we obtained different results on how financial development affects agriculture growth. The results based on integral indicators showed that the financial development does not affect agricultural growth in Ukraine. The study based on non-integrated indicators, which characterizes various aspects of the financial system's banking component and agricultural development, provided a significant link between financial system and agriculture growth. The regression models revealed if bank deposits to GDP (\%) increases the value added per worker in agriculture increases exponentially.

We found that the indicator "domestic credit to private sector by banks (\% of GDP)", which characterized the efficiency of the banking sector, showed specific dynamics in Ukraine. It means when the monetary amount of loans was increased the level of indicator was decreasing over 20042013. The reason was the high dependency of the Ukrainian economy on bank lending, which was reflected in the high elasticity of GDP to changing in lending. The specific dynamics of indicator "domestic credit to private sector by banks (\% of GDP)" is one of the reasons for the absence of a statistical dependence between the integral indicators of financial development and agricultural growth. The results of the study indicate that, agriculture is more sensitive to lending changes than the vast majority of other sectors of the economy. The increasing lending of one UAH resulted in retail turnover growth of $1.62 \mathrm{UAH}$, while agricultural gross output growth was UAH 5.06.

However, our study has several limitations. First, the results obtained are relevant only for Ukraine. From a sci- entific viewpoint, it is worth exploring the patterns that are inherent to all agrarian countries. Secondly, the study did not take into account significant differences in the activity of certain groups of agricultural producers in Ukraine. In particular, we can assume that financial development has a different impact on the activities of small and large farms.

We found arguments that indicated a positive relationship between the financial system's banking component and agriculture growth but have not completely proven this dependency. It requires developing universal methodological approaches of appraising the nexus of the financial system's banking component on agriculture growth in general as well separate farm groups for agrarian countries with bank-based financial systems. These universal methodological approaches will help to create the applied techniques for identification how the new loan programs and new financial models affect agricultural growth. The absence of these methodological approaches negatively affects the value of any future research based on empirical data.

\section{Literature}

Anthony, E. (2010). Agricultural credit and economic growth in Nigeria: an empirical analysis. Business and Economics Journal, 14, 1-7.

Beck, T., Demirguc-Kunt, A., Levine, R. \& Maksimovic, V. (2000). Financial Structure and Economic Development: Firm, Industry and Country Evidence“ (WB Working Paper WPS2423). World Bank. Retrieved from: http://documents.worldbank.org/curated/ en/2000/08/693232/financial-structure-economic-development-firm-industry-country-evidence

Demetriades, P. \& Hussein, K. (1996). Does Financial Development Cause Economic Growth? Time Series Evidence from 16 Countries? Journal of Development Economics, 51(2), 387-411, http://dx.doi.org/10.1016/ $\underline{\mathrm{S} 0304-3878(96) 00421-\mathrm{X}}$

Edison, H., Levine, L., Ricci, L., \& Sløk, T., (2002). International Financial Integration and Economic Growth. Journal of International Money and Finance, 21, 749776, http://dx.doi.org/10.1016/S0261-5606(02)00021$\underline{9}$

EFSE, (2012). Potential for agricultural finance in Ukraine: Study paper. EFSE. Retrieved from: http://www.efse. lu/media/pdfs/studies/other_sector_studies/potential-of-agricultural-finance-in-ukraine efse-df_2012 eng.pdf

Ghirmay, T. (2004). Financial development and economic growth in Sub-Saharan African countries: evidence from time series analysis. African Development Review, 16, 415-432. ISSN: 1467-8268.

Goldsmith, R.W. (1969). Financial Structure and Development. New Haven, CT: Yale University Press.

Hye, Q.M.A. \& Wizarat, S. (2011). Impact of financial 
liberalization on agricultural growth: a case study of Pakistan. China Agricultural Economic Review, 3, 191-209.

King, R. \& Levine, R. (1993). Finance and growth: Schumpeter might be right. Quarterly Journal of Economics, 108(3), 717-737, http://dx.doi.org/10.2307/2118406

Levine, R. \& Zervos, S. (1998). Stock markets, banks and economic growth. American Economic Review, 88(3), 537-558, http://dx.doi.org/10.1596/1813-9450-1690

Levine, R. (2002). Bank-based or market-based financial systems: which is better? (NBER Working Paper 9138). Cambridge, MA: National Bureau of Economic Research. Retrieved from: http://www.nber.org/papers/w9138.pdf

Manning, M. J. (2003). Finance Causes Growth: Can We Be So Sure? Contributions to Macroeconomics, 3 (1), 1-22, http://dx.doi.org/10.2202/1534-6005.1100

OECD, (2012) Implementing Credit Guarantee Schemes in Ukraine: The Case of Agribusiness, Private Sector Development, Policy Handbook. Paris: OECD. Retrieved from: https://www.oecd.org/countries/ukraine/ UkraineCGSAgribusiness.pdf

Oliynyk, O., Adamenko, V., \& Oliynyk, L. (2015). The Comparative Analysis of Financial System of Czech Republic, Poland and Ukraine. Acta Universitatis Agriculturae et Silviculturae Mendelianae Brunensis, 63(6), 2067-2076, https://doi.org/10.11118/actaun201563062067

Rajan, R. \& Zingales, L. (2003). Banks and markets: the changing character of European finance. The transformation of the European financial system, eds. In: V. Gaspar, P. Hartmann, O. Sleijpen. European Central Bank, Frankfurt. Retrieved from: https://www.ecb.europa.eu/events/pdf/conferences/zingales_comp.pdf

Schmidt, R. \& Hryckiewicz, A. (2006). Financial systems - importance, differences and convergence. Working Paper Series No. 4. Institute for Monetary and Financial Stability, Johann Wolfgang Goethe-Universität, Frankfurt am Main. Retrieved from: http://econstor.eu/ bitstream/10419/97758/1/IMFS_WP_04.pdf

Shahbaz, M., Shabbir, M. S. \& Butt, M. S. (2013). Effect of financial development on agricultural growth in $\mathrm{Pa}-$ kistan: New extensions from bounds test to level relationships and Granger causality tests. International Journal of Social Economics, 40(8), 707 - 728.

Shan, J. \& Morris, A. (2002). Does Financial Development 'Lead' Economic Growth? International Review of Applied Economics, 16 (2), 153-168, http://dx.doi. org/10.1108/IJSE-01-2012-0002

Sharif, S. J. S., Salehi, M. \& Alipour, M. (2009). Financial Markets Barriers' in Agricultural Sector: Empirical Evidence of Iran. Journal of Sustainable Development, 2, 96-101. DOI: http://dx.doi.org/10.5539/jsd.v2n3p95

The Federal Reserve System, (2015). Statistical Releases and Historical Data. Retrieved from: http://www.federalreserve.gov/releases/h8/default.htm

The National Bank of Ukraine, (2015). Bulletin of the National Bank of Ukraine. Retrieved from: http://bank. gov.ua/control/en/publish/category?cat id $=66894$

The World Bank, (2016a): World DataBank. Indicators. Retrieved from: http://data.worldbank.org/indicator

The World Bank, (2016b). World Development Indicators. Retrieved from: http://databank.worldbank.org/ data/views/variableselection/selectvariables.aspx?source=world-development-indicators\#.

Wasilewski, M., Oliynyk, O., \& Adamenko, V. (2015). Financial system and economic growth: evidence of Poland and Ukraine, Scientific Papers of the University of Szczecin - Finance, Financial Markets, Insurance, 855(74, t.2), 559 - 573, http://dx.doi.org/10.18276/ frfu.2015.74/2-49

Yazdani, S. (2008). Financial Market Development and Agricultural Economic Growth in Iran, American-Eurasian Journal of Sustainable Agriculture, 2, 338-343.

Yazdi, S. K., Khanalizadeh, B. (2014). The Financial Development and Agriculture Growth in Iran: ARDL Approach, Proceedings of the 5th International Conference on Development, Energy, Environment, Economics „Recent Advances in Energy, Environment and Financial Planning“, 335-342.

Olena Oliynyk-Dunn (Doctor of Economic Sciences) is a Head of Banking Department at the Faculty of Economics, National University of Life and Environmental Sciences of Ukraine. Her major interests concern comparative analysis of financial systems, agricultural financial system, financial support for agriculture, credit rationing and credit guarantee scheme in agriculture. She teaches at undergraduate and master level. She is author of several monographs, books and number scientific articles presented at national and international conferences and published in Ukraine and abroad. 